\title{
Meanings, Dimensions, and Categories of Mathematics Teacher Beliefs: A Navigation through the Literature
}

\author{
Shashidhar Belbase \\ University College, Zayed University, Dubai, United Arab Emirates \\ e-mail: Shashidhar.Belbase@zu.ac.ae
}

\begin{abstract}
This paper aimed to discuss the meanings, dimensions, and categories of teacher beliefs about teaching and learning mathematics. I reviewed the relevant literature about teacher beliefs in general, beliefs about mathematics, and beliefs about mathematics teaching and learning in particular. Based on the review of the literature, I outlined the meanings of teacher beliefs and conceptualized three dimensions of teacher beliefs - affective dimension, cognitive dimension, and pedagogical dimension. Then, I discussed three viewpoints to observe teacher beliefs - relational, institutional, and praxis lenses. I utilized these lenses to categorize belief constructs into three classes of beliefs about mathematics, teaching mathematics, and learning mathematics. These classes' included-instrumentalist, constructivist, and integral beliefs. I addressed the pedagogical implications of these categorical beliefs in the end.
\end{abstract}

Keywords: constructivist beliefs, dimension of beliefs, integral beliefs, instrumental beliefs, teacher beliefs.

How to Cite: Belbase, S. (2019). Meanings, Dimensions, and Categories of Mathematics Teacher Beliefs: A Navigation through the Literature. International Journal on Emerging Mathematics Education, 3(1), 1-26. http://dx.doi.org/10.12928/ijeme.v3i1.11494

\section{INTRODUCTION}

In this article, first, I present the different meanings of belief. Second, I describe three dimensions of beliefs. Third, I discuss three lenses to view teacher beliefs about mathematics and pedagogy of mathematics. Fourth, I reconceptualize teacher beliefs about mathematics and pedagogy in terms of traditional, constructivist, and integral beliefs from the literature. Finally, I conclude it with some implications of these belief categories. This paper is drawn upon my doctoral dissertation (Belbase, 2015) for the ideas discussed.

\section{Meaning of Belief}

There is no one commonly agreed upon definition of belief. There are diverse views on how educationists, psychologists, and philosophers define belief (Leder, Pehkonen, \& Törner, 2002). Mathematics education researchers define teacher beliefs in a variety of ways (Furinghetti \& Pehkonen, 2002). According to Schoenfeld (1985), mathematics-related belief systems are one's mathematical worldviews. Lester, Garofalo, \& Kroll (1989) state that beliefs constitute the individual's subjective knowledge about self, mathematics, problem-solving, and the topics that deal within problem statements. Likewise, Hart (1989) argues that belief is a certain type of judgment about a set of objects. Schoenfeld (1992) further elucidates the notion of belief as an individual's understanding and feelings that may shape the ways that he or she conceptualizes and engages in mathematical behavior. Pajares (1992) defines belief as judgment of the truth or falsity of a proposition. McAlpine, Eriks-Brophy, \& Crago 
(1996) describe belief as interrelated notions. Goldin (2002) defines belief as multiplyencoded, internal cognitive/affective configurations, to which the holder attributes the truth value of some kind. These definitions relate beliefs with internally coded configurations, worldviews, subjective knowledge, and personal judgment.

Hermans, van Braak, \& van Keer (2008) expressed belief as a set of conceptual representations. Goldin, Rösken \& Törner (2009) elaborate on four aspects to define beliefs- ontological, normative, enumerative, and affective aspects. The ontological aspect relates to the existence of a belief object. These objects can be personal, social, or epistemological in nature (Goldin et al., 2009). The normative aspect associates one's belief contents with a fuzzy set of beliefs with different weights. The enumerative belief states depth to one's conceptions (e.g., deep belief, superficial belief, peripheral belief, central belief, etc. to name a few). Affective beliefs are related to feelings, perceptions, values, and attitudes. According to the Cognitive Activation (COACTIV) Theory, "beliefs are psychologically held understandings and assumptions related to phenomena or objects in the world that seem to be true, and influence people's interactions with the world" (Voss, Kleickmann, Kunter, \& Hachfeld, 2013). Some researchers (e.g., Kalaja, Barcelos, Aro, \& Ruohotie-Lyhty, 2015) have a broader view that individual's beliefs are context dependent, dynamic, systemic, dialogic, and ideological.

Philosophers have a different way of conceptualizing beliefs. Audi (1988) discussed that belief is dependent on the perception of an object and self-consciousness that are grounded causally, justificationally, and epistemically in one's visual, tactual, audial, and other perceptual experience. He further categorized beliefs in terms of propositional and objectual. The propositional beliefs are related to a proposition that can be either true or false (e.g., Rose is a beautiful girl) whereas the objectual beliefs are related to the objects of beliefs (e.g., the tree is straight). Besides perceptual experiences, beliefs may originate from memory or retrospection of objects or events and such beliefs are memorial beliefs. Further, beliefs may also originate from introspection or imagination of events or phenomena (Audi, 1988). Another philosopher, relatively more recent, introduced a triadic view of beliefs which states that belief must be a three-place or the triadic relation among a subject, what he or she believes, and how he or she believes it (Feit, 2008).

A belief is a mental state of making a judgment of something with a degree of confidence toward it (Belbase, 2015). That means belief is associated with functional interaction or transaction between mental state through introspection and brain state through perceptual experience (Belbase, 2013a). These beliefs may originate from past experiences, experiences that work best, established beliefs in the system, personal interest, and education and training (Farrell, 2013). However, they may present or exist in one's mind or social context in psychologically held clusters instead of isolated constructs (Liljedahl, 2018a; Liljedahl, 2018b). These definitions of beliefs largely indicate three dimensions of beliefs - affective, cognitive, and pedagogical dimension. I discuss these dimensions in the following sub-sections.

\section{Dimensions of Beliefs}

I conceptualized three dimensions of teacher beliefs from the literature on beliefs about content and process in mathematics education. I discussed each of them separately under the following sub-sections. 
Affective dimension of beliefs

Affect in general means one's emotional aspect of mind. Belief means one's conception of certainty/uncertainty of something in mind. Hence, affective beliefs are associated with emotional contents in one's mind that may have different categories. Bodur, Brinberg, \& Coupey (2000) outlined eight categories of affect - aroused, elated, pleased, quiet, calm, unpleasant, bored, and distressed. Each of these affective states influences what a person thinks about an object or event leading to conceiving a belief about them. Affect and belief interact with each other. They seem to be interrelated within a dynamic system of thinking and acting in a context (Pepin \& Roesken-Winter, 2015). The emotional factors such as perceptions, feelings, appreciations, motivations, values, and attitudes are interrelated to beliefs (Furinghetti \& Pehkonen, 2002).

At the foundation level of affect, a teacher may be aware of what, how, and when to teach mathematics. The teacher may have preferences of content and related process and can initiate an action over the other. He or she may justify the reasons for the actions based on his or her beliefs. He or she may exhibit positive or negative attitudes or behavior in the classroom toward the mathematical contents and applies the pedagogy that he or she thinks right. The intention of the teacher toward such classroom actions are the results of justification of his or her thinking within his or her belief system. Such selections of activities and judgments behind them may confer his or her utmost legacy to his or her beliefs (McLeod, 1988). Therefore, an affect (feeling and emotion) may interact with one's cognition (mind and brain processes) that further shapes the person's belief in another dimension - cognitive dimension.

Cognitive dimension of beliefs

One's beliefs about teaching-learning mathematics seem to have an intricate connection to his or her cognition. The cognitive dimension is about knowledge, comprehension, perception, experience and conceptions through the active mental process. Thompson (1992) considered that one's beliefs are related to his or her knowledge and conceptions about the subject matter and process. Therefore, a person's beliefs are connected to his or her ability in recalling, describing, comprehending, reasoning and identifying the subject matter, pedagogy, and process in mathematics. His or her beliefs are concerned with mathematical rules, procedures and theories for analyzing, synthesizing, prioritizing, and categorizing the content, context, and process. He or she can assimilate, accommodate and adapt to them in solving the mathematical problems. These beliefs about mathematical knowledge content, process, and pedagogy either may come through an authority or they are constructed or created by an individual or group. The cognition and beliefs of an individual or a group may interact, inform, and update each other through affect (Eichler \& Erens, 2015) that influence mental schema or image of an object or a process. The cognitive dimension of beliefs can play an important role in determining one's beliefs about the content and pedagogical process. The mental operation of cognition provides one a content or proposition of beliefs about something (Spezio \& Adolphs, 2010) that influences action and interaction in a context shaping the relational domain, that is pedagogy. Therefore, affective and cognitive conditions of a person influence the third dimension of belief pedagogical dimension. 
Pedagogical dimension of beliefs

The pedagogical dimension is related to interpersonal beliefs (Hull, 1979), privately theoretical (Churchill, 2006), and theory-practice (praxis) oriented (Grundy, 1987). The relational aspect focuses on the teacher's relationship with the contents, processes, students, and the environment. Every teacher has his or her private theory (Garcia, 2009) that affects his or her beliefs and then actions. A teacher may have preferences of methods and approaches for teaching and learning mathematics. The private theory of content and the pedagogical process may originate from his or her observations, experiences, and learning from the theories and literature (Churchill, 2006). The nexus of theory-practice (praxis) is deeply rooted in the fundamental interests of education and its goals (Habermas, 1972). Teacher's personal or private theory may align with technical (empirical analytic), practical (historical hermeneutics), or the emancipatory (critical methods) goal of education (Grundy, 1987; Streibel, 1991). According to the teacher's personal or private theory, he or she may act either for the technical or practical or emancipatory interest of mathematical pedagogy.

These three dimensions-affective, cognitive, and pedagogical dimensions of beliefs and associated issues can be viewed from three methodological lenses relational, institutional, and praxis that formed a basis to categorize mathematics teacher beliefs. These lenses have been discussed in the research method section.

\section{RESEARCH METHOD}

The author conducted an extensive review of the literature on teacher beliefs in general and mathematics teacher (both pre-service and in-service) beliefs in particular about conceptualizing the three belief categories-traditional, constructivist, and integral beliefs. These categorization of teacher beliefs are not straightforward from the literature as different research discussed teacher beliefs differently. To do a systematic and scientific categorization the mathematics teacher beliefs, the author utilized three lenses to view those beliefs from the different literature. These lenses are were relational lens, institutional lense, and praxis lens.

\section{Relational Lens}

The interrelation of teacher beliefs and practices is a subject of study in mathematics education. Some researchers (e.g., Walker, Brownlee, Exley, Woods, \& Whiteford, 2011) mention that there is a relation between teacher beliefs and knowledge to their teaching practices. Then, it is necessary to align the teacher beliefs for reform-oriented teaching practices. However, it requires a change in teacher beliefs to influence their classroom practices. Many teachers still similarly teach mathematics as they learned it in schools and colleges (Lampert \& Ball, 1998). Lampert and Ball further mention that such complaints are common to many teacher education programs. This issue indicates that either the practicing teachers do not have much experience of reformed mathematics in the methods classes or they are not able to use those methods in their classrooms. This view contradicts the experiential learning as the process whereby knowledge is created through the transformation of experience (Kolb, 1984). Likewise, teacher beliefs can also be discussed in terms of the interrelation between conceptual and procedural knowledge (Herppich \& Witter, 2018).

In many publications, (e.g., Pepin \& Roesken-Winter, 2015) the authors highlight teacher beliefs and dynamic affect system that interact with and inform each other. Pepin \& Roesken-Winter (2015) emphasize the issues of student-teacher relation and their participation in shaping their affects and beliefs, issues in the method of studying

IJEME, Vol. 3, No. 1, March 2019, 1-26. 
belief and its interrelation with affect in mathematics education. They indicate to the pressing needs of making sense of teacher beliefs concerning the students' performance and practices in mathematics education. Therefore, it appears that there is a strong correlation between beliefs and classroom practices of teachers (Bandura, 1986; Hashweh, 1996; Pajares, 1992) and this correlation is consistent in many cases (SavasciAcikalin, 2009). However, this may not be true in other cases because of various reasons, for example, institutional goal, limitation of time, obligation to complete the course in limited time, nature of assessment, lack of administrative support for reformapproach, and parent expectations of high grades. Hence, the relational lens largely focuses on the contents of beliefs and the relationships among these contents as illustrated in Figure 1.

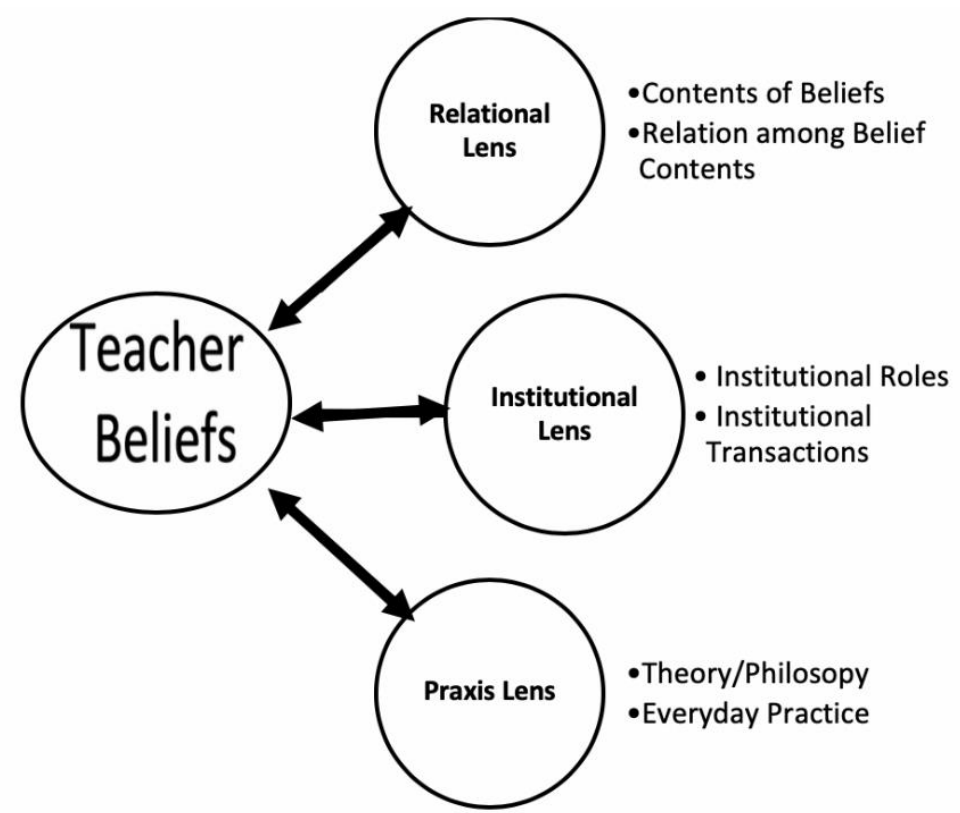

Figure 1. Three lenses to categorize mathematics teacher beliefs

\section{Institutional Lens}

There is plenty of research on teacher beliefs about the change of their beliefs for reform-oriented practices. Some of these studies before 1990 (e.g., Grant, 1984; Nespor, 1987; Peterson, Fennema, Carpenter, \& Loef, 1989; Rokeach, 1968; Stonewater \& Oprea, 1988; Thompson, 1984) emphasize the description and existence of different beliefs without a focus on change of beliefs. Other studies from 1990 to 2000 (e.g., Battista, 1994; Brosnan, Edward, \& Erickson, 1996; Brown \& Baird, 1993; Jones, 1991; Kagan, 1992; Perry, Howard, \& Tracey, 1999; Quinn, 1998a; Quinn, 1998b; Richardson, 1996; Schmidt \& Kennedy, 1990; Tillema, 1995; Witherspoon \& Shelton, 1991) seem to focus on the measurement of teacher beliefs using belief scales. These studies did not elaborate on the reasons for different beliefs. This issue is related to the shortage of studies on developing positive beliefs through education and development programs (Skott, 2015) thus by pointing the finger to the efforts of educational institutions to prepare teachers. Blömeke, Hsieh, Kaiser, \& Schmidt (2014) testify such issues related to teacher knowledge and beliefs. They outline several factors, for example, methodological, developmental, cultural and historical, social, and economic challenges. They also point to the issues of integration of beliefs with content knowledge (CK), pedagogical knowledge (PK), and pedagogical content knowledge (PCK), among others. 
These studies emphasized the role of mathematics teacher education programs for a change in teacher beliefs in a positive way to change in practice in mathematics education. The institutional lens essentially focuses on the institutional roles in forming different kinds of beliefs and how the institutional transactions shape and sustain those beliefs (See Figure 1).

\section{Praxis Lens}

We can view mathematics teachers' beliefs through praxis lens. This lens provides us with a tool to observe teacher beliefs either as a process or product (Grundy, 1987). Belief as a product is a priori concept within a program before the actual intervention or action. As a process, it is a part of unfolding beliefs based on personal interest, the influence of the teachers and others, and the environment. The view of belief as a systemic product seems static that is dependent on the educational goals and programs, and the second view of the process is a dynamic one that keeps on changing with new experiences (Streibel, 1991). The static view aligns with Habermas's technical interest with traditional instruction for an empirical-analytic method of knowledge and the process of knowing about the world. These beliefs are guided by a set of institutional and governmental policy to create a certain type of human resource to serve the society with a technical mind, and it does not have enough room for implementing personal theories and beliefs in educational practices. The dynamic or process view embraces practical or emancipatory facets of mathematics education for social transformation. These emphases embrace the historical-hermeneutic role of knowledge construction by individuals and institutions for humanity and change (Pepin \& Roesken-Winter, 2015). The emancipatory aspect emphasizes teacher beliefs, consciousness and awareness of social, political, or cultural transformations for a more equitable and just society (Streibel, 1991). Teacher beliefs can also be viewed from an epistemological perspective in terms of different philosophical paradigms (e.g., positivism, symbolism, logicism, constructivism, etc.) and their corresponding practical implications (Xenofontos, 2018). The praxis lens mostly focuses on the theoretical and philosophical canons of teacher beliefs and how these beliefs interact or inform practice (See Figure 1).

The lenses discussed above helped me in categorizing teacher beliefs about mathematics, teaching mathematics and learning mathematics. I used the relational lens to observe teacher belief contents about mathematics, mathematics teaching and learning and relation among these contents to idealize the categories of beliefs in terms of traditional, constructivist, and integral belief going beyond the classical framework of the toolbox, formalism, and problem-solving suggested by Liljedahl, Rolka, \& Rosken (2007). Then, I used the institutional lens to view institutional roles and transactions to observe whether idealized belief categories relate to the particular domain of content or process. While doing this, I examined student-teacher, student-student and studentcontent interaction and classroom environment. Finally, I applied the praxis lens to interpret the idealized domain of categories from theoretical and philosophical views and everyday practices with examples from the literature. Hence, I used these lenses to identify and conceptualize three specific categories of mathematics teacher beliefs about mathematics, teaching mathematics and learning mathematics from the past studies that are discussed in the result section.

\section{RESULTS AND DISCUSSION}

The result of the extensive review of the literature on mathematics teacher beliefs has been presented in three domains - beliefs about mathematics, beliefs about 
mathematics teaching, and beliefs about mathematics learning. Each of these domains has three conceptual categories of beliefs in terms of traditional, constructivist, and integral beliefs that came up from the analysis of teacher beliefs from the literature using three lenses discussed above.

\section{Beliefs about Mathematics}

Many studies in the past discussed teacher beliefs about mathematics. Those studies explored teacher beliefs about mathematics based on nature, utility or function, relationship with other disciplines, and methods. Aguirre (2009) described teacher beliefs about mathematics based on content domains such as algebra, geometry, calculus, and statistics and their relative degree of abstractness. The abstract nature of algebra and calculus are related to negative beliefs, and other relatively lesser abstract areas of mathematics are related to positive beliefs. These beliefs are also influenced by the perceived usefulness of the subject. For example, many teachers see algebra as a less valuable subject because it is not directly applicable in daily life problem-solving. According to Dionne (1984), mathematics teachers' beliefs can be categorized as traditional, formalist, and constructivist depending on ontological and epistemological characteristics. Later, researchers added the fourth view, as integral beliefs about mathematics.

The traditional belief about mathematics considers that it is an objective and absolute knowledge that is independent of human experience and cognition. Mathematical knowledge is independent of the knower. This kind of beliefs originated from Platonism in the philosophy of mathematics. The formalist beliefs are associated with the nature of mathematics as a formal, axiomatic, and rigorous body of knowledge with logical proofs and structures (Eichler \& Erens, 2015; Ernest, 1991). Another belief related to constructivism contemplates mathematics as a corrigible, changeable, and challengeable body of knowledge through human (individual or social) construction (Ernest, 1991; Prawat, 1992). Constructivists admit that knowledge of mathematics resides in mind, but not in reality out of it. For them, such knowledge does not have an existence out of human cognition, perception and experience (Ernest, 1991; von Glasersfeld, 1989). The integral beliefs about mathematics bridge all the three beliefs together in a (w)holistic way to observe teacher beliefs as an interrelated construct of different beliefs which cannot be strictly isolated as this or that kind. It is more related to cultural-historical-political agenda of mathematics.

Therefore, teacher beliefs about mathematics can be discussed at three levels - the traditional, constructivist, and integral level as presented in Table 1. I discuss each of these belief-levels under separate sub-sections.

Table 1. Beliefs about Mathematics

\begin{tabular}{|c|c|c|}
\hline $\begin{array}{c}\text { Belief } \\
\text { Categories }\end{array}$ & Characteristics & Relevant Literature \\
\hline Traditional & $\begin{array}{l}\text { Mathematics is absolute, } \\
\text { objective, formal, axiomatic, } \\
\text { structured, and independent of } \\
\text { the human cognition; it is a } \\
\text { collection of rules and } \\
\text { procedures, and it is a tool to } \\
\text { solve problems; mathematics } \\
\text { knowledge is fixed. }\end{array}$ & $\begin{array}{l}\text { Dionne (1984), Törner (1998), } \\
\text { Handal (2003), Shahvarani \& Savizi } \\
\text { (2007), Linnebo (2009), Furinghetti } \\
\text { \& Morselli (2011), Spillane, Hopkins } \\
\text { \& Sweet (2017), Sayers \& Andrews } \\
\text { (2018). }\end{array}$ \\
\hline
\end{tabular}


Constructivist Mathematics is relative, less formal, a creation, practical, subjective, contextual, and science of every person; and has the cognitively challenging task.

Integral
Mathematics is an integrated product of social, historical, political and cultural practices by integrating both formal and informal approaches.
Ernest (1989), Thompson (1992), Törner (1998), Shahvarani \& Savizi (2007), White-Fredette (2010), Zakaria \& Musiran (2010); Manderfeld \& Siller (2018), Sayers \& Andrews (2018).

Leatham (2002), Dede \& Uysal (2012), Ernest (2015), Furinghetti \& Morselli (2009), Nkhwalume (2013), Ernest (2015).

Traditional beliefs about mathematics

Mathematics education researchers outlined mathematics teachers' traditional belief about mathematics (Dionne, 1984; Furinghetti \& Morselli, 2009; Furinghetti \& Morselli, 2011; Handal, 2003; Törner, 1998). Teachers with traditional beliefs may consider mathematics as an objective knowledge that is external to human cognition (Ernest, 1991). Such beliefs seem to align with the Platonist view (Linnebo, 2009). The teachers with traditional beliefs consider that mathematics is an abstract knowledge that is independent of the knower. Their view appears to be aligned with positivist and a realist stance (Tracey, Perry \& Howard, 1998). They consider mathematics as an exact science (Felbrich, Kaiser, \& Schmotz, 2014). Such beliefs may harm the innovative curriculum practice that is reform-oriented and research-based teaching and learning (Handal, 2003). These teachers view mathematics as universal rules and facts and the science of elites (Shahvarani \& Savizi, 2007). These beliefs are associated with rules, exact formulas and theories for memorization (Martino \& Zan, 2011). The traditional belief about the nature of mathematics aligns with instrumentalist views that consider mathematics as a collection of rules, facts, and skills (Eichler \& Erens, 2015). The teachers emphasize the justification of mathematical knowledge from the external authorities (Ernest, 1991). They may consider mathematics as an empirical science with objectivity without a role for one's subjectivity (Ernest, 1991). They may also consider mathematical proofs as a part of didactic practice (Furinghetti \& Morselli, 2009). They may conceive such belief systems from their experience as mathematics students (Skott, 2015). These beliefs emphasize mathematics as a domain of didactic knowledge to be learned rather than constructed by students.

\section{Constructivist beliefs about mathematics}

For constructivist teachers, mathematics knowledge is both technical and practical with subjectivity and contextuality, and it is a science of every person (Shahvarani \& Savizi, 2007). According to Ernest (1989), such beliefs align with problem-solving views considering mathematics as a dynamic subject which is continuously expanding as an invention and a cultural product. In this sense, mathematics is a body of knowledge with rules, axioms, facts, concepts, ideas, and theories that are contextual, social and cultural (Zakaria \& Musiran, 2010). Within this system of beliefs, mathematics is considered as "problem-solving process, a discovery of the structure and regularities" (Felbrich et al., 2014). For constructivists, the mathematical objects are created by mathematicians and practitioners of mathematics (Dionne, 1984). Such a view seems to be aligned with the process view which considers mathematics as a process of reasoning (Törner, 1998). For them, mathematics is an 
activity with conjectures, proofs, refutations, and contradictions (Thompson, 1992). Hence, all constructivists seem to believe that knowledge of mathematics is not absolute and universal, but it is "fallible, corrigible, tentative, and evolving" (Ernest, 1991). This view further supports Polya's idea of "mathematics in the making" (Polya, 1957).

Integral beliefs about mathematics

Some teachers may have beliefs about mathematics such that there is no other mathematical truth except what we construct from social and cultural context (Ernest, 1991). Such beliefs range beyond the dualistic view of traditional and constructivist (Dede \& Uysal, 2012). It may consider the system view that is much broader than the toolbox view. According to this view, mathematics is the logical study of axioms, theorems, and proofs to solve problems (Törner, 1998). Within this view, mathematics is a science to model and solve problems in society (Felbrich et al., 2014). Some teachers may describe their beliefs about mathematics either very negatively or positively, depending on their experience with mathematics and its applications. For example, some view that "one can learn mathematics only at school, mathematics is difficult, mathematics is abstract, and it has no connection with everyday life..." (Perkkilä, 2003). These negative beliefs may connote traditional or instrumental beliefs, but not all traditional beliefs are negative. Hersh (1979) assumes that mathematics as a product of sociocultural and historical actions and efforts to help us understand the nature of the problems and solve them. Within this view, we may consider mathematics as a mental tool deeply rooted in the social, cultural, and historical origin of development and practice in the human civilizations. It is also considered as "human mathematical activity that produces mathematics" (Boyd \& Ash, 2018) that promotes creativity and thinking rather than just a linear process of problem-solving. The literature on mathematics teacher beliefs does not explicitly explain integral beliefs about mathematics though several aspects of it have been outlined together with other beliefs.

The literature on teacher beliefs about mathematics mostly focused on the nature and functions of mathematics perceived by teachers as a basis to discuss their beliefs. They did not discuss explicitly how these beliefs about mathematics are related to the origin, subtleties in development and dissemination of mathematics impacting teacher beliefs. What is mathematics? How does it originate as a domain of knowledge? How does mathematics go through developmental phases of origination, modification, communication, and reorganization? There is a large gap in the literature to address these questions of beliefs about mathematics.

\section{Beliefs about Mathematics Teaching}

There are contradictory views on teachers' beliefs about teaching mathematics. For example, some researchers (e.g., Kuhs \& Ball, 1986) classified teachers' beliefs about teaching in terms of what is focused during the teaching process. Some categorized these beliefs as-- learner-focused, content-focused with conceptual understanding, content-focused with performance, and classroom-focused. The learner-focused beliefs emphasize engaging students in the construction of the meaning of what students learn. The emphasis on content and with performance stresses on mastery of rules and procedures. The view with content-focused with conceptual understanding emphasizes understanding of meanings. The fourth view with classroom-focused is a holistic approach to focus on classroom dynamics as a community of practice in mathematics. van Zoest, Jones, \& Thornton (1994) proposed a framework emphasizing three components-learner focused interaction in the classroom, focus on conceptual 
understanding, and student performance. This framework is similar to the earlier one suggested by Kuhs \& Ball (1986). Table 2 highlights these beliefs in terms of traditional, constructivist, and integral belief profiles.

Table 2. Beliefs about Mathematics Teaching

\begin{tabular}{|c|c|c|}
\hline $\begin{array}{c}\text { Belief } \\
\text { Categories }\end{array}$ & Characteristics of Beliefs & Literature \\
\hline Traditional & $\begin{array}{l}\text { Mathematics teaching means instructing; } \\
\text { the teacher is the authority prescribing } \\
\text { rules and formulas; mathematics problems } \\
\text { stress on speed and accuracy; learning } \\
\text { means memorization of facts, rules, and } \\
\text { procedures; teacher demonstrates the } \\
\text { procedures and students follow them } \\
\text { while implementing mastery approach; } \\
\text { instructions controlled by textbooks. }\end{array}$ & $\begin{array}{l}\text { Kuhs \& Ball (1986), van } \\
\text { Zoest et al. (1994), } \\
\text { Perkkilä (2003), White- } \\
\text { Fredette (2010), Dede \& } \\
\text { Uysal (2012), Boyd \& } \\
\text { Ash (2018), Kuntze \& } \\
\text { Friesen (2018), Palmer } \\
\text { (2018). }\end{array}$ \\
\hline Constructivist & $\begin{array}{l}\text { Mathematics teaching means helping } \\
\text { students construct meanings; playing a } \\
\text { multidimensional role as mentor- } \\
\text { facilitator-teacher; encourage students to } \\
\text { act as mathematicians; argue on the } \\
\text { mathematical theories; develop } \\
\text { conceptual reasoning, and teaching to be } \\
\text { reform-oriented. }\end{array}$ & $\begin{array}{l}\text { Anderson (1996), Day } \\
\text { (1996), Perkkilä (2003), } \\
\text { Beswick (2007), } \\
\text { Beswick (2012), } \\
\text { Zakaria \& Musiran } \\
\text { (2010), Dede \& Uysal } \\
\text { (2012), Spillane et al. } \\
\text { (2017), Kuntze \& } \\
\text { Friesen (2018). }\end{array}$ \\
\hline Integral & $\begin{array}{l}\text { Mathematics teaching means integrating } \\
\text { various tools for student learning; helping } \\
\text { students to teach and learn themselves; } \\
\text { making students self-dependent in } \\
\text { learning; integrating mathematics with } \\
\text { social justice issues; teaching by calling on } \\
\text { them, hearing their voices and leading } \\
\text { them to social transformation through } \\
\text { mathematics; and integration of context } \\
\text { into the teaching of mathematics. }\end{array}$ & 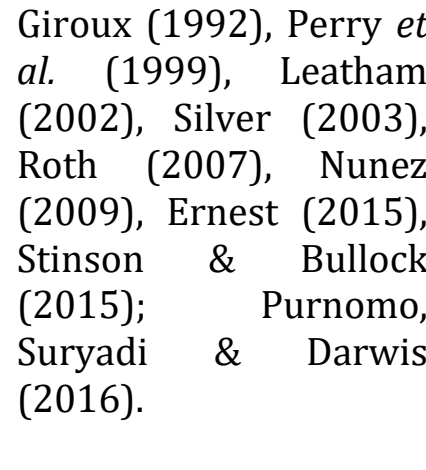 \\
\hline
\end{tabular}

Traditional beliefs about mathematics teaching

The traditional belief adopts teaching as diffusion of mathematical knowledge from a teacher to students (Ernest, 1991). This viewpoint is an instrumentalist that emphasizes the teaching of formulas, facts, skills, and procedures (Dede \& Uysal, 2012). Teaching is mostly teacher-centered with drills, lectures, repeated practices, and teacher demonstrations. The teacher is the authority of knowledge as a mathematician. He or she passes decrees of formal mathematics full of procedures, rules, and formulas, emphasizing accuracy, speed, and memorization. He or she underlines mathematical contents concentrating on students' accuracy of performance and outcomes. Teachers with this kind of beliefs mostly focus on classroom activities heavily driven by contents emphasizing accurate performance (Kuhs \& Ball, 1986). There is nothing in between right and wrong mathematics. 
For a traditional teacher, his or her role is a trainer, and the students are trainees as passive receivers of the mathematical knowledge (Ernest, 1989). A teacher with such beliefs may emphasize precise solutions demonstrating appropriate skills in solving mathematical problems. He or she highlights techniques and rules rather than mental processes. This kind of belief system can be reluctant for reforming curriculum and practice (Perkkilä, 2003). A teacher with such a belief system might be suffering from prior experience of mathematics. His or her experience and performance may be poor due to lack of understanding mathematics in the class and teacher being an authoritative figure. These teachers focus more on rote learning of rules and formulas with one correct solution to the problem rather than a discovery approach of students to construct their mathematics. They believe that textbooks are the sole resource of mathematics knowledge for teaching mathematics (Perkkilä, 2003). For them, producing the right answer in a problem-solving is more important than subjective thinking of students. They believe in instructing students with formal methods or procedures of mathematics (van Zoest et al., 1994). The teachers demonstrate the method of solving mathematics problems through the routine process and students follow their steps leading to mastery approach (Boyd \& Ash, 2018).

\section{Constructivist beliefs about mathematics teaching}

The constructivist teachers, in general, accept the students at the center of the teaching-learning. They emphasize student-centered teaching with reasoning, creative thinking, and problem-solving. According to their views, teaching embraces students "constructing their meaning as they confront with learning experiences which build on and challenge existing knowledge" (Dede \& Uysal, 2012). These teachers stress on students' understanding of the meaning and constructing their knowledge of mathematics (Kuhs \& Ball, 1986). They believe that the teacher's role is largely to be a facilitator (Ernest, 1989) and students' role is co-construction of mathematical knowledge (Zakaria \& Musiran, 2010) as mathematicians.

Some teachers emphasize cooperative, collaborative, and shared activities in the classroom (Perkkilä, 2003). The cooperative activities in mathematics class can help students in learning from each other and helping each other to learn better (Ernest, 1991). These activities accentuate teaching for conceptual and procedural understanding, the teaching of problem-solving in context, using hands-on and technological manipulatives, and helping students produce their solutions with their logic and reasoning. For the constructivist teachers, teaching is a creative-imaginative function that helps students learn mathematics by constructing their mathematical ideas. Some mathematics teachers may be slow in espousing and instigating the constructivist teaching due to their background and prior learning experiences. The constructivist teachers support problem-solving phases in teaching that include stating the problem, clarifying the variables, exploring the different possible solutions, the phase of relief from the dead end, and presenting one's solutions, and interpreting the solutions. These phases align with constructivist teaching with a statement of problems, identification of alternate solutions, avoidance of the dead end, and presentation of the solutions (van Zoest et al., 1994).

Integral beliefs about mathematics teaching

A teacher may negotiate with norms and values while developing a learning environment for students (Perry et al., 1999). Sometimes, one's beliefs do not clarify whether they are precisely traditional or constructivist; rather they extend toward both 
directions integrating the good aspects of either of the belief paradigms. Therefore, teaching mathematics can be viewed from an integral approach beyond the traditionalconstructivist separation as a methodological border-crossing (Giroux, 1992; Silver, 2003).

This view focuses on the devolution of the disciplinary and interdisciplinary border of mathematics. The idea of border-crossing is a revelation of an integrated approach to teaching mathematics. The border-crossing is beyond traditionalconstructivist dualities of mathematics teaching, and it gears one's actions toward critical and postmodern 'deconstruction of current mathematics teaching' (Nkhwalume, 2013). The postmodern view of teaching can transcend further with self-reflexivity (Cain, 2011) of a teacher on the relationship of content and pedagogy with self through an introspection, retrospection, prospection, and idiosyncratic construction of mathematical meaning (Belbase, 2013b). This view decenters mathematics teaching with opportunities for planning students' active engagement and construction of mathematics (Goss, Powers, \& Hauk, 2013). In such cases, the teaching of mathematics may not have explicit boundaries to state whether it is traditional or constructivist (Smitherman, 2006). Therefore, it is a contextual and provisional process requiring an adjustment in the classroom based on cultural-historical context (Roth \& Lee, 2007). Teachers may defy the ability groups and apply mixed groups so that integration of low performers and slow learners benefit from collaboration with high ability students in a variety of ways (Boyd \& Ash, 2018). Such teachers believe on the integration of social and cultural context while teaching mathematics (Purnomo et al., 2016).

The discussion on mathematics teacher beliefs about mathematics teaching should highlight 'What constitutes teaching?' as an important question to consider for analysis of belief categories. From the viewpoint of the institutional transaction, it is a process by which teachers help students to learn mathematics in the schools. Then, a question arises-What are the elements of these institutional transactions taking place within the schools in which teachers are engaged in so-called action of teaching? Do their expressed views reflect their beliefs about mathematics teaching? Do their actions in the classroom or elsewhere in schools exhibit their beliefs about mathematics teaching? Are these expressions consistent with their beliefs? Are their actions consistent with their beliefs? Are their beliefs consistent with what they exhibit through expressions or actions? Teaching mathematics is a very dynamic complex process that is, metaphorically, like a wind that does not have a fixed direction, origin, and also uniform impact. The literature on teacher beliefs about teaching mathematics has not yet fully explored the subtle nature of beliefs system besides categorizing them with specific signposts as - instrumental, reform-oriented, integrated, etc. Although, there is plenty of literature on mathematics teacher beliefs about teaching mathematics, there is still scope of further studies to develop a deeper understanding of such beliefs with new categories.

\section{Beliefs about Mathematics Learning}

Mathematics teachers may have different beliefs about mathematics learning. Some researchers and scholars (e.g., Fisher, 1992) related beliefs about learning mathematics in terms of knowing mathematics contents and procedures. Learning of mathematics is related to mathematical cognition with mental operations. The cognitive process includes reception of information, assimilation of received information, adoption of the information in a context, adaptation of the knowledge into changed context, construction of meaning and interpretation of what has been learned,

IJEME, Vol. 3, No. 1, March 2019, 1-26. 
evaluation of the knowledge, and extension into other areas of problems. Skemp (1971) and Skemp (1978) proposed mathematics learning either as relational and instrumental function. Some teachers may believe instrumental learning which focuses on traditional approaches in the classroom with rote learning, drill-and-practice, memorization of rules, and repeated practice of problem-solving (Ernest, 1991). The instrumental learning highlights the use of formal rules, symbols, procedures, and formulas without adaptation (Idris, 2006). The teachers who believe relational learning may emphasize contextual learning by the construction of meaning and concepts by the students (Kim \& Albert, 2015). They may construct a scheme (mental structure), and they may use the scheme to transfer concepts across the contents (Skott, 2015). The prior schema may form a network of new schemas with adaptation and transformation of knowledge (Idris, 2006).

Some teachers consider that learning mathematics is an active process of construction of meaning by students. Others consider that learning mathematics is guided by teacher motivation, direction and instruction (Wang \& Hsieh, 2014). The former view about the construction of meaning is known as active learning in which students design their approaches to solve mathematical problems. The latter view, a form of passive learning, assumes that "students learn mathematics through following explanations, rules, and procedures transmitted by the teachers" (Wang \& Hsieh, 2014). Therefore, there are conflicting views about learning mathematics-- some of which are close to traditional and others are near constructivist or integral beliefs. Table 3 summarizes teacher beliefs about mathematics learning in terms of three categories-traditional, constructivist, and integral beliefs.

Table 3. Beliefs about Learning Mathematics

\begin{tabular}{|c|c|c|}
\hline $\begin{array}{l}\text { Belief } \\
\text { Categories }\end{array}$ & Characteristics of Beliefs & Related Literature \\
\hline Traditional & $\begin{array}{l}\text { Mathematics learning is memorizing } \\
\text { rules, formulas, procedures, and facts; } \\
\text { these rules, formulas, and facts are } \\
\text { transmitted from the authority (i.e., a } \\
\text { teacher) into the minds of students; and } \\
\text { teaching mathematics is preaching, and } \\
\text { learning is assimilating what is preached. }\end{array}$ & $\begin{array}{l}\text { Schwier \& Misanchuk } \\
\text { (1993), Dengate \& } \\
\text { Lerman (1995), Ernest } \\
\text { (1995), Dunn (2002), } \\
\text { Perkkilä } \\
\begin{array}{l}\text { Zakaria \& Musiran } \\
\text { (2010). }\end{array}\end{array}$ \\
\hline Constructivist & $\begin{array}{l}\text { Mathematics learning is a process of } \\
\text { constructing meaning; mathematical } \\
\text { concepts, procedures, and theories are } \\
\text { constructed by students through the } \\
\text { individual and social process; and } \\
\text { learning mathematics is either intuitive or } \\
\text { mediated through interaction; students } \\
\text { connect their prior experience to new } \\
\text { learning of mathematics. }\end{array}$ & $\begin{array}{l}\text { Steffe \& Kieren (1994), } \\
\text { Dengate \& Lerman } \\
\text { (1995), Ernest (1995), } \\
\text { Furinghetti \& Morselli } \\
\text { (2009), Lo \& Anderson } \\
\text { (2010), Purnomo, et al. } \\
\text { (2016). }\end{array}$ \\
\hline Integral & $\begin{array}{l}\text { Mathematics learning includes self- } \\
\text { reflective and reflexive processes; } \\
\text { problem-solving is integrated into other } \\
\text { disciplines; learning of math contents } \\
\text { takes place in a context; and learning } \\
\text { mathematics involves integrating theory }\end{array}$ & $\begin{array}{l}\text { Steffe \& Gale (1995), } \\
\text { Leatham (2002), } \\
\text { Nagata (2004), Roth } \\
\text { (2007), Ernest (2015), } \\
\text { Boyd \& Ash (2018). }\end{array}$ \\
\hline
\end{tabular}


and practice in social-cultural-historical context; students learn through struggles and mistakes.

Traditional beliefs about mathematics learning

Some mathematics teachers have traditional beliefs about learning mathematics. Their beliefs may support the exogenic philosophy and behaviorist theories of learning. Those who believe that knowledge should reflect the external reality consider that learning is reflecting the real world with reproduction of what has been learned from experience (senses) (Hermans, 2002). According to this view, the teacher is the authority of mathematics knowledge who transmits facts, rules, and procedures into the minds of students (Dengate \& Lerman, 1995). Those teachers consider that learning is memorizing facts, rules, and formulas (Ernest, 1991). Their metaphor of mind is a 'tabula rasa' (a blank slate), and the world is the absolute reality (Ernest, 1995). However, the world may be the absolute Newtonian world (determinism), or it is a social and cultural world (human agency). Those mathematics teachers consider that learning is a passive reception of knowledge from the external authorities (e.g., teachers) without being sceptical of what students learn and how they learn. Many mathematics teachers, still today, embrace this type of belief. According to Zakaria \& Musiran (2010) and Perkkilä (2003), a majority of teachers (in their study) believed learning of mathematics as memorizing rules, procedures, and formulas. Such beliefs focus on mastering procedural skills (Ernest, 1989). Therefore, still these days many mathematics teachers believe these models of passive reception, submissive and compliant learning.

Constructivist beliefs about mathematics learning

Some mathematics teachers believe that learning is the construction of meaning by the learners. Their beliefs about mathematics learning align with the endogenic philosophy and constructivist theories of learning. Their viewpoints about learning mathematics are inclusive in the sense of adopting and adapting to the culturalhistorical activities in day-to-day life (Dengate \& Lerman, 1995; Roth \& Lee, 2007; Steffe \& Kieren, 1994). They consider that the mind is an active site of constructing mathematical knowledge and the world of knowledge represents inner cognitive, intuitive, and the experiential world (Ernest, 1995). Many mathematics teachers hold this belief about learning mathematics. Lo and Anderson (2010) stated that many preservice teachers believed learning mathematics by creating a challenging and supportive environment to build upon students' experiences. Mathematics learning can be either an individual or a social process of conceiving concepts, meanings, and procedures. Students construct their meaning of mathematical knowledge through selfreflection and critical thinking. They may work collaboratively to teach and learn from each other (Brodie, 2010). According to this view, mathematics learning is an inductive process with cases, examples, and problems shifting the goal to the broad-spectrum of understanding the phenomena. Ernest (1989) argued constructivist learning as an active construction of meaning, exploration of mathematical ideas, and learner autonomy. It is a process of transitioning from simple to complex construction of mathematical concepts and ideas with meanings (Furinghetti \& Morselli, 2009; Furinghetti \& Morselli, 2011). While doing this, students work on their problems and question themselves - is it right or wrong and collaboratively check each other's work without going to the teacher (Boyd \& Ash, 2018). Such teacher believes that students 
connect their prior experience to the new concepts of mathematics they learn in the classroom (Purnomo et al., 2016).

Integral beliefs about mathematics learning

Some mathematics teachers consider that the teachers can help all students learn mathematics by creating a learning environment for everyone who wishes to learn (Leatham, 2002). The postmodern view of learning considers that learning is an active engagement in the reflexive thinking, reasoning and problem-solving. Such process encompasses retrospective, intuitive, prospective, and idiosyncratic thinking and reasoning about mathematical problems (Belbase, 2013a; Nagata, 2004). Teachers' selfreflexive thinking and acting in the teaching process help students in problem-solving by integrating knowledge across the disciplines or the content areas in the same discipline. Learning mathematics is an integral process of accommodating a variety of cognitive, affective, social, cultural, and historical resources available. Therefore, such teachers may encourage students to learn from intricacies and contexts by enhancing their potential and developing them as self-learners (Steffe \& Gale, 1995) considering themselves as agents of social and cultural transformation with a resilience (Taylor, Taylor, Karnovsky, \& Taylor, 2017). While doing this, students participate in collaborative learning by embracing "struggle and mistakes" (Boyd \& Ash, 2018). When the students struggle through the problems and resolve their mistakes, they not only try it again but also apply different methods or procedure to solve the problem either independently or with peer collaboration.

Learning mathematics is related to the ability to recall, define, explain, compare, apply, comprehend, conjecture, refute, conceptualize, synthesize, and construct mathematical objects in a context. There can make a list of many other action-verbs related to the learning of mathematics. However, teacher beliefs about mathematics learning in terms of traditional, constructivist, and integral beliefs may not integrate all of these aspects. Most of the literature on teacher beliefs about learning mathematics focused on conceptual and procedural aspects of problem-solving with manipulation, representation, construction, justification, simplification and extension of mathematical objects. Very few works of literature are concerned with teacher beliefs about learning mathematics in terms of neurophysiological, psychological, philosophical, social, political, institutional, and individual factors that constitute the meaning of learning mathematics. A plethora of literature on teacher beliefs about learning mathematics deal with action related belief constructs rather than metacognitive and reflexive thinking of students that have long term impacts on their ability to develop own mathematics and related concepts, models, and theories.

\section{CONCLUSION}

Mathematics teacher beliefs may have a significant implication in the quality of teaching and learning in the classroom. Teacher beliefs are the principal factors to influence instructional activities in the classroom and subsequent student learning (Skott, 2015). Many researchers agree that teacher beliefs may affect their classroom practices and hence developing positive beliefs is essential for changing their teaching practice (Stipek, Givvin, Salmon, \& MacGyvers, 2001). Likewise, other scholars and researchers (e.g., Fives \& Buehl, 2012; Schoenfeld, 1992) emphasized teacher beliefs about the subject matter, teaching and learning process, and students as significant determinants of the classroom process. Therefore, one of the goals of teacher development and education is associated with forming positive beliefs. This goal is 
possible to achieve with advanced mathematical content and pedagogical knowledge including social, cognitive, and affective components (Schoenfeld, 2010). Therefore, mathematics teacher education should aim to form and change teacher beliefs for a change in practice (Richardson, 2003). Mathematics education researchers (e.g., Peterson et al., 1989; Stipek et al., 2001; Thompson, 1992) emphasized forming and changing such beliefs for a change in teaching and learning of mathematics. Understanding of teachers existing beliefs helps teacher educators to plan and implement professional development activities that support reform-oriented teachinglearning practices with a flexibility to adopt new knowledge, skills and practices transforming their instructional beliefs (Spillane et al., 2017).

In this context, mathematics teacher education can influence teachers' beliefs in a positive way for improved practice (Fenstermacher, 1979; Green, 1971). Hence, one of the goals of current mathematics teacher education is to transform beliefs about teaching and learning (Fenstermacher, 1979). Then, a question comes: How to change teacher beliefs? This question points to the methodological issues of how to form or change their beliefs and mechanism for change of beliefs. The process of forming positive beliefs about mathematics and teaching-learning mathematics is related to mechanisms for forming and changing their beliefs. These processes are linked with broader epistemic factors associated with teacher beliefs. The review of studies shows the possibility of different models for forming and changing teacher beliefs. These models can be helpful in the epistemic change in teacher education leading to a focus on shaping constructivist and integral beliefs (Alexander \& Sinatra, 2007; Sinatra, 2005). The process of forming or changing beliefs may affect one's epistemology and methodology as well (Chandler, Boyes, \& Ball, 1990) by formulating and implementing new strategies (Schommer et al., 1992). The process of shaping beliefs for reformoriented teaching and learning of mathematics is also related to conceptual change (Qian \& Alvermann, 1995), one's cognitive ability (Kardash \& Howell, 2000), moral reasoning (Bendixen, Schraw, \& Dunkle, 1998), and overall academic performance (Cano \& Cardelle-Elawar, 2008). Many teacher education programs focus on teacher beliefs as part of their interventions to impart positive beliefs for meaningful actions in the classroom (Part, 2009). The results of international studies (e.g., TIMSS and PISA) may provide us with a motivation to develop or reform mathematics teacher education to change or shape teacher beliefs for more meaningful practices in the classrooms (Part, 2009). However, the literature on teacher beliefs about mathematics, teaching mathematics and learning mathematics focused largely on the content and object of beliefs and less on the context leaving a space for further research and development on this complex issue.

\section{ACKNOWLEDGEMENT}

This article is a part of my graduate study at the University of Wyoming, Laramie, Wyoming, USA and I would like to acknowledge the support and care of my supervisors, Dr Larry Hatfield and Dr Linda Hutchison while I was working on this research. I want to thank the anonymous reviewers for comments and feedback on this manuscript.

\section{REFERENCES}

Aguirre, J. M. (2009). Teacher domain-specific beliefs and their impact on mathematics education reform. In J. Maas \& W. Schlöglmann (Eds.), Beliefs and attitudes in mathematics education: New research results (pp. 45-58). Rotterdam: Sense Publisher. 
Alexander, P. A., \& Sinatra, G. M. (2007). First steps: Scholar's promising movements into a nascent field of inquiry. In S. Vosniadou, A. Baltas, \& X. Vamvakoussi (Eds.), Reframing the conceptual change approach in learning and instruction (pp. 221236). Oxford: Elsevier.

Anderson, J. (1996). Some teachers' beliefs and perceptions of problem solving. In P. C. Clarkson (Ed.), Technology of mathematics education (pp. 30-37). Melbourne: MERGA.

Audi, R. (1988). Belief, justification, and knowledge: An introduction to epistemology. Belmont: Wadsworth Publishing Company.

Bandura, A. (1986). Social foundations of thought and action: A social cognitive theory. Englewood Cliffs: Prentice Hall.

Battista, M. T. (1994). Teacher beliefs and the reform movement in mathematics education. Phi Delta Kappan, 75(6), 462-470.

Belbase, S. (2013a). A unified theory of mind-brain relationship: Is it possible? Open Journal of Philosophy, 3(4), 443-450.

Belbase, S. (2013b). Beliefs about teaching geometric transformations with geometers' Sketchpad: A reflexive abstraction. Journal of Education and Research, 3(2), 15-38.

Belbase, S. (2015). Preservice secondary mathematics teachers' beliefs about teaching geometric transformations using Geometer's Sketchpad. Dissertation. Laramie: University of Wyoming.

Bendixen, L. D., Schraw, G., \& Dunkle, M. E. (1998). Epistemic beliefs and moral reasoning. Journal of Psychology, 13, 187-200.

Beswick, K. (2007). Teachers' beliefs that matter in secondary mathematics classrooms. Educational Studies in Mathematics, 65, 95-120.

Beswick, K. (2012). Teachers' beliefs about school mathematics and mathematicians' mathematics and their relationship to practice. Educational Studies in Mathematics, 79, 127-147.

Blömeke, S., Hsieh, F. J., Kaiser, G., \& Schmidt, W. H. (Eds.). (2014). International Perspectives on Teacher Knowledge, Beliefs and Opportunities to Learn TEDS-M Results. New York: Springer.

Bodur, H. O., Brinberg, D., \& Coupey, E. (2000). Belief, affect, and attitude: Alternate models of the determinants of attitude. Journal of Consumer Psychology, 9(1), 1728.

Boyd, P., \& Ash, A. (2018). Mastery mathematics: Changing teacher beliefs around inclass grouping and mind set. Teaching and Teacher Education, 75, 214-223.

Brodie, K. (2010). Teaching mathematical reasoning in secondary school classrooms. New York: Springer.

Brosnan, P. A., Edwards, T., \& Erickson, D. (1996). An exploration of change in teachers' beliefs and practices during implementation of mathematics standards. Focus on Learning Problems in Mathematics, 18(4), 35-53.

Brown, A. B., \& Baird, J. (1993). Inside the teacher: Knowledge, beliefs, and attitudes. In P. Wilson (Ed.), Research ideas for the classroom: High school mathematics (pp. 245-259). New York: Macmillian. 
Cain, T. (2011). Teacher's classroom-based action research. International Journal of Research \& Method in Education, 34(1), 3-16.

Cano, F., \& Cardelle-Elawar, M. (2008). Family environment, epistemological beliefs, learning strategies, and academic performance: A path analysis. In M. S. Khine (Ed.), Knowing, knowledge, and beliefs: Epistemological studies across diverse cultures (pp. 219-240). New York: Springer.

Chandler, M., Boyes, M., \& Ball. L. (1990). Relativism and stations of epistemic doubt. Journal of Experimental Child Psychology, 50, 370-395.

Churchill, D. (2006). Teachers' private theories and their design of technology-based learning. British Journal of Educational Technology, 37(4), 559-576.

Day, R. (1996). Case studies of preservice secondary mathematics teachers' beliefs: Emerging and evolving themes. Mathematics Education Research Journal, 8(1), 522.

Dede, Y., \& Uysal, F. (2012). Examining Turkish preservice elementary teachers' beliefs about the nature and the teaching of mathematics. International Journal of Humanities and Social Science, 2(12), 125-135.

Dengate, B., \& Lerman, S. (1995). Learning theory in mathematics education: Using the wide angle lens and not just the microscope. Mathematics Education Research Journal, 7(1), 26-36.

Dionne, J. J. (1984). The perception of mathematics among elementary school teachers. In J. M. Moser (Ed.), Proceedings of 6th conference of the North American Chapter of the International Group of the Psychology of Mathematics Education (pp. 223228). Madison: University of Wisconsin.

Dunn, M. L. (2002). Theories of learning. In Learning and Teaching Briefing Papers Series, Headington: Oxford Brookes University.

Eichler, A., \& Erens, R. (2015). Domain-specific belief systems of secondary mathematics teachers. In B. Pepin, B. Roesken-Winter (eds.), From beliefs to dynamic affectis: 179-200). New York: Springer.

Ernest, P. (1989). The impact of beliefs on the teaching of mathematics. In P. Ernest (Ed.), Mathematics teaching: The state of the art (pp. 249-254). New York: The Falmer Press.

Ernest, P. (1991). The philosophy of mathematics education. New York: Routledge Falmer.

Ernest, P. (1995). The one and many. In L. P. Steffe \& J. Gale (Eds.), Constructivism in education (pp. 459-486). Hillsdale: Lawrence Erlbaum.

Ernest, P. (2015). Postmodern mathematics. In S. J. Cho (Ed.), The Proceedings of the 12th International Congress on Mathematics Education (pp. 605-608). Seoul: Springer International Publishing.

Farrell, T. S. C. (2013). Reflective practice in ESL teacher development groups. London: Palgrave Macmillan.

Feit, N. (2008). Belief about the self: A defense of the property theory of content. Oxford: Oxford University Press. 
Felbrich, A., Kaiser, G., \& Schmotz, C. (2014). The cultural dimension of beliefs: An investigation of future primary teachers' epistemological beliefs concerning nature of mathematics in 15 countries. In S. Blömeke et al. (Eds.), International perspectives on teacher knowledge, beliefs and opportunities to learn: TEDS-M results (pp. 209-229). New York: Springer.

Fenstermacher, G. (1979). A philosophical consideration of recent research on teacher effectiveness. In L. S. Shulman (Ed.), Review of research in education (Vol. 6, pp. 157-185). Itasca: Peacock.

Fisher, P. O. (1992). Beliefs about and attitudes toward mathematics and mathematics teaching held by prospective elementary teachers at the University of NebraskaLincoln. Dissertation. Lincoln: University of Nebraska-Lincoln.

Fives, H., \& Buehl, M. M. (2012). Spring cleaning for the messy construct of teacher beliefs: What are they? Which have been examined? What can they tell us? In K. R. Harris, S. Graham \& T. Urdan (Eds.), APA Educational Psychology Handbook (Vol. 2, pp. 471-499). Washington DC: APA.

Furinghetti, F., \& Morselli, F. (2009). Every unsuccessful problem solver is unsuccessful in his or her own way: Affective and cognitive factors in proving. Educational Studies in Mathematics, 70, 71-90.

Furenghetti, F., \& Morselli, F. (2011). Beliefs and beyond: Hows and whys in the teaching of proof. ZDM Mathematics Education, 43, 587-599.

Furinghetti, F., \& Pehkonen, E. (2002). Rethinking characterizations of beliefs. In G. C. Leder, E. Pehkonen, \& G. Törner (Eds.), Beliefs: A hidden variable in mathematics education (pp. 39-58). Dordrecht: Kluwer Academic Publishers.

Garcia, G. (2009). The role of pedagogical beliefs in teachers' integration of technology in the classroom. Mansfield: University of Connecticut.

Giroux, H. A. (1992). Border crossing: Cultural workers and the politics of education. New York: Routledge.

Goldin, G. A. (2002). Affect, meta-affect, and mathematical beliefs structures. In G. C. Leder, E. Pehkonen, \& G. Törner (Eds.), Beliefs: A hidden variable in mathematics education (pp. 59-72). Dordrecht: Kluwer Academic Publishers.

Goldin, G., Rösken, B., \& Törner, G. (2009). Beliefs- no longer a hidden variable in mathematics teaching and learning process. In J. Maas \& W. Schlöglmann (Eds.), Beliefs and attitudes in mathematics education: New research results (pp. 1-18). Rotterdam: Sense Publisher.

Goss, M., Powers, R., \& Hauk, S. (2013). Identifying change in secondary mathematics teachers' pedagogical content knowledge. Proceedings for the 16th conference on Research in Undergraduate Mathematics Education. Denver: SIGMAA.

Grant, C. E. (1984). A study of the relationship between secondary mathematics teachers' beliefs about teaching-learning process and their observed classroom behaviors. Dissertation. Grand Forks: University of North Dakota.

Green, T. (1971). The activities of teaching. New York: McGraw-Hill.

Grundy, S. (1987). Curriculum: Product or praxis? New York: Falmer Press.

Habermas, J. (1972). Knowledge and human interests (2nd ed.). London: Heinemann. 
Handal, B. (2003). Teachers' mathematical beliefs: A review. The Mathematics Educator, 13(2), 47-57.

Hart, L. E. (1989). Describing the affective domain: Saying what we mean. In D. B. McLeod \& V. Adams (Eds.), Affect and mathematical problem solving: A new perspective (pp. 33-45). New York: Springer-Verlag.

Hashweh, M. Z. (1996). Effects of science teachers' epistemological beliefs in teaching. Journal of Research in Science Teaching, 33(1), 47-63.

Hermans, C. A. M. (2002). Ultimate meaning as silence: The monologic and polyphonic Author-God in religious communication. In C. A. M. Hermans, G. Immink, A. de Jong \& J. van der Lans (Eds.), Social constructionism and theology (pp. 113-146). Boston: Brill.

Hermans, R., van Braak, J., \& Van Keer, H. (2008). Development of the beliefs about primary education scale: Distinguishing a developmental and transmissive dimension. Teaching and Teacher Education, 24(1), 127-139.

Herppich, S., \& Wittwer, J. (2018). Preservice teachers' beliefs about students' mathematical knowledge structure as a foundation for formative assessments. Teaching and Teacher Education, 76, 242-254.

Hersh, R. (1979). Some proposals for reviewing the philosophy of mathematics. Advances in Mathematics, 31, 31-50.

Hull Jr, R. E. (1979). On pedagogical caring. Educational theory, 29(3), 237-243.

Idris, N. (2006). Teaching and learning of mathematics: Making sense and developing cognitive abilities. Negara: Utusan Publications.

Jones, D. L. (1991). A study of the beliefs systems of two beginning middle school mathematics teachers. Dissertation. Athens: University of Georgia.

Kagan, D. M. (1992). Implications of research on teacher beliefs. Educational Psychologist, 27(1), 65-90.

Kalaja, P., Barcelos, A. M. F., Aro, M., \& Ruohotie-Lehty, M. (2015). Beliefs, agency, and identity in foreign language learning and teaching. New York: Palgrave Macmillan.

Kardash, C. M., \& Howell, K. L. (2000). Effects of epistemological beliefs and topicspecific beliefs on undergraduates cognitive and strategic processing of dualpositional text. Journal of Educational Psychology, 92(3), 524-535.

Kim, R., \& Albert, L. R. (2015). Mathematics teaching and learning: South Korean elementary teachers' mathematical knowledge for teaching. New York: Springer.

Kolb, D. A. (1984). Experiential learning: Experience as the source of learning and development. Eaglewood Cliffs: Prentice-Hall.

Kuhs, T. M., \& Ball, D. L. (1986). Approaches to teaching mathematics: Mapping the domains of knowledge, skills, and dispositions. East Lansing: Michigan State University, Center for Teacher Education.

Kuntze, S., \& Friesen, M. (2018). The role of mathematics teachers' views for their competence of analyzing classroom situations. In B. Rott et al. (Eds.), Views and beliefs in mathematics education (pp. 183-194). Switzerland: Springer.

Lampert, M., \& Ball, D. L. (1998). Teaching multimedia and mathematics: Investigations of real practice. New York: Teachers College, Columbia University.

IJEME, Vol. 3, No. 1, March 2019, 1-26. 
Leatham, K. R. (2002). Preservice secondary mathematics teachers' beliefs about teaching with technology. Dissertation. Athens: University of Georgia.

Leder, G. C., Pehkonen, E., \& Törner, G. (Eds.). (2002). Beliefs: A hidden variable in mathematics education. Dordrecht: Kluwer Academic Publisher.

Lester, F. K., Garofalo, J., \& Kroll, D. L. (1989). Self-confidence, interest, beliefs, and metacognition: Key influences on problem-solving behavior. In D. B. McLeod \& V. Adams (Eds.), Affect and mathematical problem solving: A new perspective (pp. 7588). New York: Springer-Verlag.

Liljedahl, P. (2018a). Relationship between proxies for learning and mathematically related beliefs. In H. Palmer \& J. Skott (Eds.), Students' and teachers' values, attitudes, feelings, and beliefs in mathematics classrooms (pp. 1-11). Switzerland: Springer.

Liljedahl, P. (2018b). Affect as a system: The case of Sara. In B. Rott et al. (Eds.), Views and beliefs in mathematics education (pp. 21-32). Switzerland: Springer.

Liljedahl, P., Rolka, K., \& Rösken, B. (2007). Affecting affect: The re-education of preservice teachers' beliefs about mathematics and mathematics learning and teaching. In M. Strutchens \& W. Martin (Eds.), 69th NCTM yearbook - The learning of mathematics (pp. 319-330). Reston: National Council of Teachers of Mathematics.

Lo, W. Y., \& Anderson, J. (2010). Beyond the curriculum: The mathematical beliefs of pre-service primary teachers in Hong Kong. In L. Sparrow, B. Kissane, \& C. Hurst (Eds.), Shaping the future of mathematics education: Proceedings of the 33rd annual conference of the Mathematics Education Research Group of Australasia (pp. 657-644). Fremantle: MERGA.

Manderfeld, K., \& Siller, H. S. (2018). Evaluation of an approach of professional role reflection in mathematics education. In B. Rott et al. (Eds.), Views and beliefs in mathematics education (pp. 103 - 113). Switzerland: Springer.

Martino, P. D., \& Zan, R. (2011). Attitude toward mathematics: A bridge between beliefs and emotions. ZDM Mathematics Education, 43, 471-482.

McAlpine, L., Eriks-Brophy, A., \& Crago, M. (1996). Teaching beliefs in Mohawk classrooms: Issues of language and culture. Anthropology \& Education Quarterly, 27(3), 390-413.

McLeod, D. B. (1988). Affective issues in mathematical problem solving: Some theoretical considerations. Journal of Research in Mathematics Education, 19, 134141.

Nagata, A. L. (2004). Promoting self-reflexivity in intercultural education. Journal of Intercultural Communication, 8, 139-167.

Nespor, J. (1987). The role of beliefs in the practice of teaching. Journal of Curriculum Studies, 19(4), 317-328.

Nkhwalume, A. A. (2013). The plausibility of a postmodern pedagogy of mathematics in the African context. Mathematical Theory and Modeling, 3(5), 112-117.

Nunez, I. (2009). Activity theory in mathematics education. Proceedings of the British society for research into learning mathematics, 29(2), 53-57. 
Linnebo, O. (2009). Platonism in the philosophy of mathematics. In E. N. Zalta (Ed.), The Stanford Encyclopedia of Philosophy. Stanford: Metaphysics Research Lab, Stanford University.

Pajares, F. (1992). Teachers' beliefs and educational research: Cleaning up a messy construct. Review of Educational Research, 62(3), 307-322.

Palmer, H. (2018). How to understand changes in Novice mathematics' talk about good mathematics teaching? In B. Rott et al. (Eds.), Views and beliefs in mathematics education (pp. 127-136). Switzerland: Springer.

Part, I. (2009). An empirical study on beliefs of pre-service teachers. In J. Maas \& W. Schlöglmann (Eds.), Beliefs and attitudes in mathematics education: New research results (pp. 131-142). Rotterdam: Sense Publisher.

Pepin, B., \& Roesken-Winter, B. (Eds.). (2015). From beliefs to dynamic affect systems in mathematics education: Exploring a mosaic of relationships and interactions. New York: Springer.

Perkkilä, P. (2003). Primary school teachers' mathematics beliefs and teaching practices. Proceedings of the Third Conference of the European Society for Research in Mathematics Education. Bellaria: University of Pisa.

Perry, B., Howard, P., \& Tracey, D. (1999). Head mathematics teachers' beliefs about the learning and teaching of Mathematics. Mathematics Education Research Journal, 11, 39-57.

Peterson, P. L., Fennema, E., Carpenter, T. P., \& Loef, M. F. (1989). Teachers' pedagogical content beliefs in mathematics. Cognition and Instruction, 6(1), 1-40.

Polya, G. (1957). How to solve it (2nd ed.). London: Penguin Books.

Prawat, R. (1992). Teachers' beliefs about teaching and learning: A constructivist perspective. American Journal of Education, 100, 354-395.

Purnomo, Y. W., Suryadi, D., \& Darwis, S. (2016). Examining preservice elementary school teacher beliefs and instructional practices in mathematics class. International Electronic Journal of Elementary Education, 8(4), 629-642.

Qian, G., \& Alvermann, D. (1995). Role of epistemological beliefs and learned helplessness in secondary school students' learning science concepts from text. Journal of Educational Psychology, 87(2), 282-292.

Quinn, R. J. (1998a). The influence of mathematics methods course on preservice teachers' pedagogical beliefs concerning manipulatives. The Clearing House: A Journal of Educational Strategies, Issues and Ideas, 71(4), 236-238.

Quinn, R. J. (1998b). Technology: Preservice teachers' beliefs and the influence of a mathematics methods course. The Clearing House: A Journal of Educational Strategies, Issues and Ideas, 71(6), 375-377.

Richardson, V. (1996). The role of attitudes and beliefs in learning to teach. In J. Sikula (Ed.), The handbook of research in teacher education (pp. 102-119). New York: Macmillan.

Richardson, V. (2003). Preservice teachers' beliefs. In J. Raths \& A. C. McAninch (Eds.), Teacher beliefs and classroom performance: The impact of teacher education (pp.122). Greenwich: Information Age Publishing. 
Rokeach, M. (1968). Beliefs, attitudes and values. San Francisco: Jossey-Bass.

Roth, W. -M., \& Lee, Y.-J. (2007). "Vygotsky's neglected legacy": Cultural-historical activity theory. Review of Educational Research, 77(2), 186-232.

Savasci-Acikalin, F. (2009). Teacher beliefs and practices in science education. AsiaPacific Forum on Science Learning and Teaching, 10(1).

Sayers, J., \& Adrews, P. (2018). Developing and trailing a simple-to-use instrument for surveying teacher education students' mathematics-related beliefs. In $\mathrm{H}$. Palmer \& J Skott (Eds.), Students' and teachers' values, attitudes, feelings, and beliefs in mathematics classrooms (pp. 77-88). Switzerland: Springer.

Schmidt, W. H., \& Kennedy, M. M. (1990). Teachers' and teacher candidates' beliefs about subject matter and about teaching responsibilities. East Lansing: Michigan State University.

Schoenfeld, A. H. (1985). Mathematical problem solving. Orlando: Academic Press.

Schoenfeld, A. H. (1992). Learning to think mathematically: Problem solving, metacognition, and sense-making in mathematics. In D. A. Grouws (Ed.), Handbook of research on mathematics learning and teaching (pp. 334-370). New York: Macmillan.

Schoenfeld, A. H. (2010). How we think: A theory of goal-oriented decision making and its educational implications. New York: Routledge.

Schommer, M., Crouse, A., \& Rhodes, N. (1992). Epistemological beliefs and mathematical text comprehension: Believing it is simple does not make it so. Journal of Educational Psychology, 6, 39-42.

Schwier, R. A., \& Misanchuk, E. R. (1993). Interactive multimedia instruction. New Jersey: Educational Technology Publications.

Shahvarani, A., \& Savizi, B. (2007). Analyzing some Iranian-High School teachers' beliefs on mathematics, mathematics learning, and mathematics teaching. Journal of Environmental \& Science Education, 2(2), 54-59.

Silver, E. A. (2003). Border crossing: Relating research and practice in mathematics education. Journal for Research in Mathematics Education, 34, 182-184.

Sinatra, G. M. (2005). The "warming trend" in conceptual change research: The legacy of Paul Pintrich. Educational Psychologist, 40, 107-115.

Skemp, R. R. (1971). The psychology of learning mathematics. Harmondsworth Middlesex: Penguin Books.

Skemp, R. R. (1978). Relational understanding and instrumental understanding. Arithmetic Teacher, 26(3), 9-15.

Skott, J. (2015). Towards a participatory approach to 'beliefs' in mathematics education. In B. Pepin \& B. Roesken-Winter (Eds.), From beliefs to dynamics affect systems in mathematics education: Exploring a mosaic of relationships and interactions (pp. 323). New York: Springer.

Smitherman, S. E. (2006). Reflections on teaching a mathematics education course. Dissertation. Baton Rouge: Louisiana State University. 
Spezio, M. L., \& Adolphs, R. (2010). Emotion, cognition, and beliefs: Findings from cognitive neuroscience. In T. Bayne \& J. Fernandez (Eds.), Delusion and selfdeception (pp. 86-106). New York: Taylor \& Francis Group.

Spillane, J. P., Hopkins, M., \& Sweet, T. M. (2017). School district educational infrastructure and change at scale: Teacher peer interactions and their beliefs about mathematics instruction. American Educational Research Journal, 55(3), 532-571.

Steffe, L. P., \& Gale, J. (1995). Constructivism in education. Hillsdale: Lawrence Erlbaum.

Steffe, L. P., \& Kieren, T. (1994). Radical constructivism and mathematics education. Journal for Research in Mathematics Education, 25(6), 711-733.

Stinson, D. W., \& Bullock, E. C. (2015). Critical postmodern methodology in mathematics education research: Promoting another way of thinking and looking. Athens: Georgia State University.

Stipek, D. J., Givvin, K. B., Salmon, J. M., \& MacGyvers, V. L. (2001). Teachers' beliefs and practices related to mathematics instruction. Teaching and Teacher Education, $17(2), 213-226$.

Stonewater, J. K., \& Oprea, J. M. (1988). An analysis of in-service teachers' mathematical beliefs: A cognitive development perspective. In M. J. Behr, C. B. Lacampagne, \& M. M. Wheeler (Eds.), Proceedings of the 10th Annual Conference of the North American Chapter of the International Group for the Psychology of Mathematics Education (pp. 356-363). DeKalb: Northern University.

Streibel, M. J. (1991). Instructional design and human practice: What can we learn from Habermas's theory of technical and practical human interests? Proceedings of selected research presentations at the annual convention of the Association for Educational Communications and Technology. Bloomington: AECT.

Taylor, E., Taylor, P. C., Karnovsky, S., Aly, A., \& Taylor, N. (2017). “Beyond Bali”: A transformative education approach for developing community resilience to violent extremism. Asia Pacific Journal of Education, 37(2), 193-204.

Thompson, A. G. (1984). The relationship of teachers' conceptions of mathematics and mathematics teaching to instructional practice. Educational Studies in Mathematics, 15, 105-127.

Thompson, A. G. (1992). Teachers' beliefs and conceptions: A synthesis of research. In D. A. Grouws (Ed.), Handbook of research on mathematics teaching and learning (pp. 127-146). New York: Macmillan.

Tillema, H. H. (1995). Changing the professional knowledge and beliefs of teachers: A training study. Learning and Instruction, 5(4), 291-318.

Törner, G. (1998). Self-estimating teachers' views on mathematics teaching- modifying Dionne's approach. In S. Berenson, K. Dawkins, M. Blandon, W. Coulombe, J. Kolb, K. Norwood, \& L. Stiff (Eds.), Proceedings of the Twentieth Annual Meeting of the North American Chapter of the International Group for the Psychology of Mathematics Education (Vol. 2, pp. 628-634). Columbus: International Group for the Psychology of Mathematics Education.

Tracey, D., Perry, B., \& Howard, P. (1998). Teacher beliefs about the learning and teaching of mathematics: Some comparisons. Adelaide: Mathematics Education Research Group of Australasia. 
Van Zoest, L., Jones, G. A., \& Thornton, C. A. (1994). Beliefs about mathematics teaching held by pre-service teachers involved in a first grade mentorship program. Mathematics Education Research Journal, 6(1), 37-55.

von Glasersfeld, E. (1989). Cognition, construction of knowledge, and teaching. Synthese, 80(1), 121-140.

Voss, T., Kleickmann, T., Kunter, M., \& Hachfeld, A. (2013). Mathematics teachers' beliefs. In M. Kunter, J. Baumert, W. Blum., U. Klusmann, S. Krauss, \& M. Newbrand (Eds.), Cognitive activation in the mathematics classroom and professional competence of teachers: Results from the COACTIV Project (pp. 249-272). New York: Springer.

Walker, S. M., Brownlee, J., Exley, B., Woods, A., \& Whiteford, C. (2011). Personal epistemology in preservice teachers: Beliefs changes throughout a teacher education course. In J. Brownlee, G. Schraw, \& D. Berthelsen (Eds.), Personal epistemology and teacher education (pp. 84-99). New York: Routledge.

Wang, T. -Y., \& Hsieh, F. -J. (2014). The cultural notion of teacher education: Comparison of lower-secondary future teachers' and teacher educators' beliefs. S. Blömeke et al. (Eds.), International perspectives on teacher knowledge, beliefs and opportunities to learn: TEDS-M results (pp. 255-277). New York: Springer.

White-Fredette, K. (2010). Why not philosophy? Problematizing the philosophy of mathematics in a time of curriculum reform. The Mathematics Educator, 19(2), 2131.

Witherspoon, M., \& Shelton, J. (1991). Measuring elementary school teachers' beliefs about teaching mathematics: A preliminary report. New Orleans: Association of Teacher Educators.

Xenofontos, C. (2018). Greek-Cypriot elementary teachers' epistemological beliefs about mathematics. Teaching and Teacher Education, 70, 47-57.

Zakaria, E., \& Musiran, N. (2010). Beliefs about the nature of mathematics, mathematics teaching and learning among trainee teachers. The Social Sciences, 5(4), 346-351. 
